\title{
The Medical Construction of Homosexuality and its Relation to the Law in Nineteenth-Century England
}

\author{
IVAN DALLEY CROZIER*
}

It was clear to him that the experimental method was the only method by which one could arrive at any scientific analysis of the passions. ${ }^{1}$

Historians of homosexuality have paid much attention to the law of England, and particularly to sodomy trials, in order to gauge both what was generally thought of samesex practices in the past, and how the legal profession went about framing such practices as illegal. "Unnatural practices" were regarded as a felony in England following Henry VIII's 1533 decree that the "offenders being hereof convict by verdict confession or outlawry shall suffer such paynes of death and losses and penalties of their goods chattles debts lands tenaments and hereditaments as felons being accustomed to do accordynge to the order of the Common Lawes of this Realme". ${ }^{3}$ In 1967, under advice from the Wolfenden Report that the law was not preventing same-sex activity, male homosexual practices carried out in private were decriminalized. ${ }^{4} \mathrm{~A}$ great deal of historical attention has been directed towards the law, and especially to the many existing court records, in

* Ivan Dalley Crozier, $\mathrm{PhD}$, The Wellcome Trust Centre for the History of Medicine at UCL, Euston House, 24 Eversholt Street, London NW1 $1 \mathrm{AD}$.

I would like to thank Peter Bartlett, Marina Bollinger, W F Bynum, Katie Fullagar, Alex Goldbloom, Rictor Norton, and the anonymous reviewers at Medical History for their comments on a draft of this paper. This article was written whilst I was a graduate student in the School of Science and Technology Studies, UNSW, Sydney, 2052, Australia.

\footnotetext{
' Oscar Wilde, The picture of Dorian Gray, Harmondsworth, Penguin Books, 1985, p. 84.

${ }^{2}$ See, for a representative sample, Rictor Norton, The myth of the modern homosexual,
}

London, Cassell, 1997; Randolph Trumbach, 'Sex, gender, and sexual identity: male sodomy and female prostitution in Enlightenment London', J. Hist. Sexuality, 1991-2, 2: 186-203; Jeffrey Weeks, Coming out: homosexual politics in Britain from the nineteenth century to the present, London, Quartet Books, 1977; A N Gilbert, 'Buggery and the British Navy 1700-1861', J. soc. Hist., 1976, 10: 72-98.

${ }^{3}$ The Act of 25 Hen. VIII c. 6 ; first enacted by Parliament in 1533, reproduced in Montgomery Hyde, The other love, Boston, Little Brown, 1970, frontispiece.

${ }^{4}$ Hyde, op. cit., note 3 above, frontispiece, writes, "With the exception of the penalties of death and forfeiture of property, for which life imprisonment was substituted in 1861, the Act remained in substance on the Statute Book until 1967". That is, sodomy was a punishable felony. 


\section{Ivan Dalley Crozier}

order to understand homosexual sub-cultures of the past; ${ }^{5}$ scholars have also addressed the presuppositions about homosexuality which were held by the legal profession. ${ }^{6}$ Furthermore, historians of homosexuality have regularly considered medical discourses in order to establish the "official" view of homosexuality which was held in England in the nineteenth century; the most common source in these efforts has been England's premier sex psychologist, Havelock Ellis. ${ }^{7}$ Nevertheless, far more attention has been directed towards Continental sex psychology, for historians seem to have believed Havelock Ellis's claim that there was no serious medical writing on homosexuality in England prior to his own work, and less to the organization of medical knowledge about homosexuality in England ${ }^{8}$ Since one feature common to both Continental and English medical discourses about same-sex practices was the movement from the focus on physical signs of sodomy used to convict "perverts" to the construction of a "homosexual type" in medical writing, this lack of attention cannot be because what was happening in England was different to the development of sex psychology on the Continent. In the last analysis, however, English medical discourses are not given the prominence of either Continental psychological texts or English legal writing by historians of homosexuality. One of the aims of this paper is rectify this situation.

A further reason why historians may have directed their focus away from England as a site for pre-Ellisian medical discourses about homosexuality could be that the majority of scholars read the surfaces of discourses over and against an analysis of the practices which underlay the construction of same-sex activity in England. In other words, works not explicitly about homosexuality have been overlooked because the practices which were described by medical authors have not been given the

\footnotetext{
${ }^{5}$ See, for example, the attention which has been paid to the most famous nineteenth-century sodomy trial, Regina v. Boulton and Others (Park), Queen's Bench, May, 1871. William Roughead's, Bad companions, Edinburgh, W Green, 1930 , pp. $149-83$, seems to have been the first historical account of Boulton and Park, and has been used to frame those of most later writers, such as Hyde, op. cit., note 3 above, pp. 94-8; Ronald Pearsall, The worm in the bud, London, Weidenfield and Nicolson, 1969, pp. 461-7. The best account of the trial is William Cohen, Sex scandal: the private parts of Victorian culture, Durham, NC, and London, Duke University Press, 1996, pp. 73-129. Recently to hand is Charles Upchurch, 'Forgetting the unthinkable: cross-dressers and British society in the case of the Queen vs. Boulton and others', Gender Hist., 2000, 12: 127-57.

${ }^{6}$ See Neil Bartlett Who was that man? A present for Mr Oscar Wilde, London, Serpent's Tail, 1988, pp. 93-163; Jeffrey Weeks, 'Inverts, perverts, and Mary-Annes: male prostitution and the regulation of homosexuality in England in the nineteenth and twentieth centuries', in idem, Against nature, London, Rivers Oram Press, 1991, pp. 43-68. Alan Sinfield, The Wilde century: effeminacy, Oscar Wilde, and the queer moment,
}

London, Cassell, 1994, addresses the differences between Weeks and Neil Bartlett on Boulton and Park.

${ }^{7}$ See Lesley Hall, 'Heroes or villains? Reconsidering British sexology of the fin de siècle', in Lynne Segal (ed.), New sexual agendas, Basingstoke, Macmillan, 1997, pp. 1-16; some of the papers in Vernon A Rosario (ed.), Science and homosexualities, London and New York, Routledge, 1997, and in Lucy Bland and Laura Doan (eds.), Sexology in culture, Cambridge, Polity Press, 1998; and Weeks, op. cit., note 2 above.

${ }^{8}$ Havelock Ellis, Sexual inversion, Philadelphia, F A Davis, 1915, 'Introduction'. Much attention has been directed towards Continental sex psychology: see Jörg Hutter, 'The social construction of homosexuals in the nineteenth century: the shift from sin to the influence of medicine in criminalizing sodomy in Germany', J. Homosex., 1993, 24: 73-93; Gert Hekma, 'A history of sexology: social and historical aspects of sexuality', in Jan Bremmer (ed.), From Sappho to De Sade: moments in the history of sexuality, New York, Routledge, 1989, pp. 173-93, and many of the articles in Rosario (ed.), op. cit., note 7 above. 


\section{The Medical Construction of Homosexuality}

emphasis they deserve. Perhaps this situation has arisen because medical and social historians are less interested in the social construction of knowledge than their colleagues in the history of science? Certain medical historians have, however, addressed the social construction of knowledge at length, and have argued that the historian can examine how discourses were produced at the institutional and negotiational level. ${ }^{9}$ Such a social constructivist focus considers the intellectual and social politics and practices which made the production of medical texts possible, instead of examining only the ideologies maintained by certain practitioners or even discursive fields. In the case of writing about homosexuality specifically and about sexuality in general, as Lesley Hall has shown, institutional pressures existed so that English doctors did not explicitly engage in writing about sex. ${ }^{10}$ This means that the sources for nineteenth-century English medical history of same-sex behaviour and of homosexuality are hidden in books on venereology, forensic medicine, criminology and hypnotism, when it was written about at all. This situation changed to a great degree with the writings of Havelock Ellis.

Following some of the hints provided by social constructivists, I would like to explore the relationship between the two main fields which historians of homosexuality have considered: medicine and law. It is crucial for this paper to explain the ways in which certain varieties of medical practitioners strove for half a century to produce legitimate discourses about same-sex activity-something which had been the privilege of the law in England. " This task initially involves considering forensic medical discourses about sodomy describing how medical practitioners produced texts which could facilitate legal proof of sodomy, while also making it necessary to consult medical opinion in the absence of other evidence; a point emphasized in the trial of Boulton and Park (1871) which used the expertise of seven medical practitioners to establish whether a crime had been committed. This paper also addresses the development of other types of medical discourse about homosexuality in Englandvenereology, behavioural psychology and later sex psychology-in relation to the law, showing that changes in discursive constructions of homosexuality can be seen as the deployment of a variety of strategies to gain a legitimate position from which to describe same-sex practices. Of course, these different facets of medical writing on homosexuality are not to be conflated to suggest that a coherent body of medical thought about same-sex practices existed. On the contrary, there existed independent fields of discourse which had their own "rules" of construction, even though they

\footnotetext{
${ }^{9}$ For a recent essay review which considers these problems in relation to the history of medicine, see Ludmilla Jordanova, 'The construction of medical knowledge', Soc. Hist. Med., 1995, 8: 361-81. Science studies have long been using these techniques. See Steven Shapin's review of the sociology of scientific knowledge, 'Here and everywhere: sociology of scientific knowledge', Annual Rev. Sociol., 1995, 25: 289-321.

${ }^{10}$ Lesley Hall, "“The English have hot water bottles": the morganatic marriage between sexology and medicine since William Acton', in
}

\author{
Roy Porter and Mikulas Teich (eds), Sexual \\ knowledge, sexual science, Cambridge University \\ Press, 1994, pp. 350-66. \\ "As already mentioned, there was a great \\ reticence for English doctors to engage explicitly \\ and solely in writing about sexuality, for it was \\ often assumed that they would appear less \\ respectable in the eyes of their peers; see ibid. Of \\ course, this does not mean that no medical \\ practitioners wrote about such topics, but the \\ same practitioners might not have comparable \\ successes in the medical world as, say, an \\ ophthalmic surgeon.
}


all existed under the ægis of medical practice. The fact that venereology and sex psychology are both medical specialities does not mean that their practitioners have anything approaching identical ideas about human sexuality. In the case of sex psychology, practitioners such as Ellis strove to formulate a position whereby the law would be revoked, and homosexuality would be an issue for psychologists rather than lawyers. On the other hand, venereologists formulated more specific tests for the forensic expert to aid in the detection of sodomy.

Running throughout this paper is the idea that the law acted as an antagonistic force against which medical discourses were framed. It is partially influenced by Roger Smith, who has shown how psychological models of criminal behaviour had a small role to play in the defining of certain crimes, although he did not consider cases of homosexuality or other "sexual perversions". Smith noted that "The judiciary considered medical theory pretentious and showed little sympathy with medical men who tried to explain the grounds on which they based their opinions". ${ }^{2}$ The same can be said of sex psychological discourses about homosexuality, which had no impact on the law during the late nineteenth and early twentieth centuries. However, Smith also emphasized that, on the whole, there were considerable pressures towards conformity and co-operation between physicians and lawyers in the use of medical evidence. This is borne out by the analysis of Boulton and Park; it should be recalled, however, that Havelock Ellis's widely read works on homosexuality were not cited in forensic medical texts until after his death, so that they did not have the legal impact that he intended. ${ }^{13}$

\section{Medicine in Nineteenth-Century England}

During the nineteenth century, medicine began its steady pilgrimage towards professionalization; in 1800 the Royal College of Surgeons was given its charter, thus raising the social esteem of Fellows and Members of the College of Surgeons. There was a close knitting of powerful interests amongst the directing Fellows of the College. At the same time there were also more radical developments within the organization of medicine in England. New medical ideas were being imported from the continent. ${ }^{14}$ Professionalization of medical practice widened the gap between

\footnotetext{
${ }^{12}$ Roger Smith, Trial by medicine: insanity and responsibility in Victorian trials, Edinburgh University Press, 1981, on p. 109. See also idem, 'Legal frameworks for British psychiatry', in G Berrios and $\mathrm{H}$ Freeman, 150 years of British psychiatry, London, Gaskell, 1991, pp. 137-51; idem, 'Expertise and causal attribution in deciding between crime and mental disorder', Soc. Stud. Sci., 1985, 15: 67-98

${ }^{13}$ For a discussion of the growing acceptance of sexological and psychoanalytical concepts of homosexuality in the criminal justice system in England in the inter-war period, see Chris Waters, 'Havelock Ellis, Sigmund Freud and the state: discourses of homosexual identity in interwar Britain', in Bland and Doan (eds), op. cit., 7 above.
}

\author{
${ }^{14}$ See Adrian Desmond, The politics of \\ evolution, Chicago University Press, 1989; Pauline \\ Mazumdar, 'Anatomical physiology and the \\ reform of medical education: London, 1825-35', \\ Bull. Hist. Med., 1983, 57: 230-46. For an \\ example pertaining to the importation of sexual \\ knowledge from France, see William Acton, 'On \\ the condition and treatment of venereal disease in \\ Paris, from notes taken from a recent visit to the \\ French metropolis', Lancet, 1850, ii: 51-3; and \\ idem, 'Remarks on the present treatment of \\ venereal disease in the hospitals of Paris, as \\ observed during a recent visit to that city', Lond. \\ med. J., 1850, ii: 605-7
}




\section{The Medical Construction of Homosexuality}

official medical work and that of "quacks". This was especially the case with the passing of the 1815 Apothecaries' Act, which recognized minimum standards of official medical practice and licensing, although it did not have the desired effect of criminalizing quackery, and the 1858 Medical Act, which set up the Medical Register, the General Medical Council, and established minimum standards of medical education, although it did not break down the system of hierarchies which existed both between the Colleges and the Worshipful Society of Apothecaries and between Members and Fellows of the Colleges. ${ }^{15}$ This new-found professionalization of medical practice was consolidated by the Royal Colleges' ability to monopolize training and hospital placements. Medical specialization, which essentially involved more doctors writing about a smaller part of medicine in more detail, also stemmed from the nineteenth century.

The ability to specialize moved the medical practitioner away from general medical knowledge, and allowed him to corner a market in the treatment of a particular area. Specialization provided a space for new types of medical practice which had not been given room to grow when carried out as a part of regular medical practice. For the purposes of this paper, it was the development into specialities of forensic medicine, venereology, and later sex psychology which was of great importance, as was the financial gain which specialization made possible. As Jeanne Peterson has noted, "Men's motives for engaging in medical profiteering and medical specialism often grew out of a desperate search for economic survival or ambition" ${ }^{16}$ Before Anne Digby's fine work, the financial aspect of being a medical practitioner was largely overlooked. Digby argues that "the importance of the financial relationship between practitioner and patient soon suggests some of the deficiencies of seeing the process of medical professionalisation as a simple power relationship in which doctors increasingly dominated their clients". Instead, in Digby's view, "there is a more even balance between the financial standing of the patient and the clinical expertise of the doctor". ${ }^{17}$ Digby also considers specialization as an attempt to play the economic aspects of medicine, noting the "Victorian trend to move into specialisms as a way of carving out new career possibilities in response to changing market opportunities". ${ }^{18}$ With such in mind, it is worthwhile considering how the structure of medical practice, the changing demography of England (where more and more people lived in an urban environment, especially in London), the economic imperative behind both the patient seeking medical treatment and the doctor seeking to better his lot, and the ability to corner a market in order to facilitate this improvement of the doctor's material conditions can be drawn together as a motor of change behind medical knowledge, including the specialities which constructed same-sex activity.

Against this medical backdrop it is essential to note that the medicalization of homosexuality was hampered by the law being the most important single field of

\footnotetext{
${ }^{15}$ See M Jeanne Peterson, The medical profession in mid-Victorian London, Berkeley, University of California Press, 1978.

${ }^{16}$ Ibid., p. 248; see also Anne Digby, Making

a medical living, Cambridge University Press, 1994, pp. 33-4.
}

${ }^{17}$ Digby, op. cit., note 16 , above, p. 6.
${ }^{18}$ Ibid., p. 44 . 


\section{Ivan Dalley Crozier}

discourse which could comment upon "unnatural practices". If this situation were to change-if it were possible for medical writers to discuss the etiology of homosexuality and other sexual problems - then another object could be medicalized. But in order for this to happen, homosexuality had to be wrested from the clutches of the law. The traditional distaste of mainstream surgeons and physicians for commenting upon sexual topics, especially upon homosexuality, had to be overcome for this to happen, as already noted. It could be argued that this avoidance of sexual topics by most doctors was the impetus behind the developing interest in sex by the nascent specializations of venereology and sex psychology, for they were essentially filling a gap in the market and in the stock of knowledge by addressing sex as a serious medical issue.

\section{The Medicalization of Sodomy: Forensic Medicine}

It is well known that detailed descriptions of same-sex acts - particularly sodomyinitially developed within forensic medical circles, but not necessarily because of a wide knowledge of sodomy held by physicians. In fact, relatively little was written on same-sex practices, regardless of the number of cases which had gone before the English courts since 1533. The major medical jurisprudence text in England prior to Alfred Taylor's works ${ }^{19}$ was T R and J B Beck's Elements of medical jurisprudence. Although the Becks were American, they discussed British law. ${ }^{20}$ In the concluding section of a chapter on rape, the Becks thought a "few words are necessary on the crime against nature". In keeping with pre-psychological theorizing about the nature of homosexuality, they pointed out the physical signs which may betray evidence of sodomy, suggesting that "[i]t may be required to examine the individual on whom it has been committed". If committed without consent, the signs of "inflammation, excoriation, heat, and contusion, will probably be present". In cases where the act was repeated, "a dilatation of the sphincters, ulceration on the parts, or a livid appearance, and thickening" would be visible. "It has been suggested that secondary symptoms of lues [syphilis] might be mistaken for these", but the Becks were "hardly of this opinion". The Becks also noted that "[n]o man, however, ought to be condemned on medical proofs solely: the physician should only deliver his opinion in favour or against an accusation already preferred". ${ }^{21}$

The most prominent contributions to jurisprudential medicine came from the famous practitioner and expert witness, Alfred Taylor. Taylor's Manual of medical

\footnotetext{
${ }^{19}$ See review of A S Taylor's Manual of medical jurisprudence, in Dublin Med. J., in the fly leaves of Taylor, $A$ manual of medical jurisprudence, 2nd ed., London, John Churchill, 1846, which positions Beck's text in the contemporary forensic medical literature. For more on the general context of sexual forensic medicine, see Thomas C Forbes, Surgeons at the Bailey: English forensic medicine to 1878, New Haven and London, Yale University Press, 1985, esp. Introduction and pp. 86-91 for a discussion
}

of forensic proofs of rape. Forbes does not address the evidence given in sodomy trials.

${ }^{20}$ For a detailed study of the Becks, see James Mohr, Doctors and the law: medical jurisprudence in nineteenth-century America, Oxford University Press, 1993, pp.15-28. Other chapters in the book also deal with the Becks.

${ }^{21}$ T R Beck and J B Beck, Elements of medical jurisprudence, 7th ed., London, John Anderson, 1842 , p. 119. 


\section{The Medical Construction of Homosexuality}

jurisprudence dealt with all aspects of the subject, and was continually updated from the 1840s until well into the twentieth century. Taylor elusively defined sodomy as "the unnatural connection of a man with man". He noted that the evidence required to establish it "is the same as in rape, and therefore penetration alone is sufficient to constitute it". However, there existed two major differences between sodomy and rape: "it is not necessary to prove the offence to have been committed against the consent of the person upon whom it was perpetrated"; both parties, "if consenting, are equally guilty". Taylor specified that a case of sodomy could be brought before the courts only when anal penetration had taken place; "if it is done elsewhere it is not sodomy". ${ }^{22}$ Taylor also noted that sodomy was "commonly sufficiently proved without medical evidence". ${ }^{23}$

In his next series of writings about sodomy and the law, Taylor added that unless the individual "be in a state of insensibility, it is not possible to conceive that this offence should be perpetrated in an adult of either sex against the will of the party". He suggested that the "slightest resistance will suffice to prevent its perpetration". Furthermore, Taylor established that "the perpetration of the act during a natural state of sleep was contrary to all probability" ${ }^{24} \mathrm{He}$ also suggested that in some cases, "proof of the fact may be obtained by resorting to microscopial evidence"; 25 that is, semen could be found in the anus of the "passive" party.

These remarks about the physical signs of sodomy were composed before England's most celebrated "homosexual" trial, $R$. v. Boulton and Park. In this trial, Boulton and Park were accused of conspiring to commit, and of committing, unnatural acts. One of the most interesting aspects of $R$. v. Boulton and Park is that seven medical practitioners were called to give evidence. This aspect of the medicalization of homosexuality is particularly important, as reaction to the legal question of homosexuality was one of the chief motors behind the development of sex psychology, especially in England. ${ }^{26}$ Boulton and Park were arrested wearing dresses to a theatre

${ }^{22}$ Taylor, op. cit., note 19 , above, pp. $560-1$. Specifically, this meant that same-sex fellatio was not illegal; something which would change in 1885, under the Law Amendment Act. See F B Smith, 'Labouchère's amendment to the Criminal Law Amendment Act', Hist. Stud., 1976, 17: 165-75. However, a case of fellatio could lead to a charge of conspiracy to commit sodomy, but, as William Cohen as shown, this charge amounted to proving whether or not sodomy had been committed, op. cit., note 5, above, pp. 87-9. For more on Taylor, see Noel G Coley, 'Alfred Swaine Taylor, MD, FRS (1806-1880): forensic toxicologist', Med. Hist., 1991, 34: 409-27, esp. pp. 412-15.

${ }^{23}$ Taylor, op. cit., note 19 , above, p. 561 .

${ }^{24}$ A S Taylor, Principles and practice of medical jurisprudence, London, John Churchill, 1865 , vol. 2 , p. 1018.

${ }^{25}$ A S Taylor, Manual of medical jurisprudence, London, John Churchill, 1849, p. 644.

\footnotetext{
${ }^{26}$ The same was the case in Germany, where the two newest approaches to same-sex activity after 1850 were Karl Heinrich Ulrichs, who theorized that a homosexual person was one with the physical body of one sex, and the soul of the other (see John Addington Symonds' contribution to Ellis and Symonds, Sexual Inversion, Watford, London University Press, 1897, repr. New York, Arno Press, 1975, Appendix C, 'Ulrichs's View'), and Johann Casper's 'Ueber Nothzucht und Päderastie und deren Ermittelung Seitens des Gerichtesarztes', Vierteljahrschrift für gerichtliche öffentliche Medizin, 1852, 1, repr. in Joachim Hohmann (ed.), Der unterdrückte Sexus, Berlin, Achenbach, 1977, pp. 239-70. Casper addressed the writing of Paul Zacchias, the seventeenth-century legal scholar, on the issue of proof of sodomy. This was expanded in $\mathrm{J}$ L Casper, $A$ handbook of the practice of forensic medicine, based upon personal experience, 4 vols, trans. G W Balfour, London, The Sydenham Society, 1861 (I), 1862 (II), 1864
} 


\section{Ivan Dalley Crozier}

in London in 1870. Taylor subsequently made some noteworthy comments on the two men:

[t]he charge against the defendants was that of conspiracy to commit or to incite to the commission of immorality. The defendants were young men who had for some time gone about to public places dressed as women, and had been seen on public occasions to associate with men as if they were women of the town.... When dressed as fashionable women, they imposed upon all who saw them. These practices had gone on at intervals for one or two years before they were detected and exposed. The defence was, that they had dressed themselves as women for the purpose of performing at private theatricals, but this did not account for all the circumstances proved against them by eye-witnesses as well as by their correspondence with many persons who were believed to be accomplices. They also assumed female names, and used them in correspondence with men. ${ }^{27}$

While most secondary attention to this trial has centred on how notions of homosexual identity were constructed by the law, I should like to develop a different trajectory, and indicate how the medical profession created its own discourses in a legal setting, by dealing entirely with the physical signs attendant on whether or not anal penetration had taken place.

On the 9 May 1871, at the Queen's Bench at Westminster Hall, the Attorney General, Mr Archibald, addressed the court on the matter of the Queen v. Boulton and others (Park). ${ }^{28}$ In particular, Archibald paid attention to medical evidence. $\mathrm{He}$ stressed that on their arrest, the prisoners were inspected by Mr Paul, who concluded that "there were appearances in their persons which indicated habitual sodomy". 29 Mr Archibald thought it "fortunate" that "there is little learning or knowledge upon this subject in this country; there are other countries in which I am told learned treatises are written as to the appearance to be expected in such cases. Fortunately Doctors in England know very little about these matters". Mr Archibald could not have made a better summary of the position of forensic knowledge about sodomy and about homosexual practices. We have seen that the Becks and Taylor had noted

(III), 1865 (IV), esp. volume three. After Casper, scholars like Benjamin Tarnowsky, The sexual instinct and its morbid manifestations from the double standpoint of jurisprudence and psychiatry, trans. W C Costello and Alfred Allinson, Paris, Charles Carrington, 1898 [orig. 1885], and

Richard von Krafft-Ebing, Psychopathia sexualis, with especial reference to contrary sexual instinct: a medico-legal study, trans. C G Chaddock, from 7th German ed., Philadelphia, F A Davis, 1892 [orig. 1886], addressed the forensic aspects of same-sex activity. Thus the development of sex psychology on the Continent was not totally removed from the issue of homosexuality and the legal problem which exacerbated writing on same-sex activity either.

${ }^{27}$ A S Taylor, Principles and practice of medical jurisprudence, ed. T Stevenson, 3rd ed., London, John Churchill, 1883, vol. 2, p. 459.

${ }^{28}$ The transcriptions of this trial are taken from Public Record Office DPP4/6. Referencing follows under headings (e.g., 'The evidence of Mr. Paul'). A fuller examination of the construction of medical evidence in the trial and its relationship to wider social issues is due to appear in Gary Edmond and Ivan Crozier, 'The importance of being ignorant: the construction of medical evidence in $R$. v. Boulton and Park', forthcoming. For other aspects of the trial, see Cohen, op. cit., note 5 above.

${ }^{29}$ There is some problem with the legality of Paul's initial investigations. The Lord Chief Justice of the Central Criminal Courts (Cockburn) reproved Paul for his cavalier activities, which were not authorized by either the police or a magistrate. See Cohen, op. cit., note 5 above, p. 79. There are some obvious similarities between the enforced investigations of Boulton and Park and the investigations of prostitutes sanctioned by the contemporary Contagious Diseases Acts. 


\section{The Medical Construction of Homosexuality}

the appearances one might expect; but these opinions were not based on great practical experience. It was the general lack of medical experience and knowledge in such matters which was the most prominent feature of this case.

Mr James Thomas Paul, Divisional Surgeon to the East Division of the Metropolitan Police for eight years, was the first to examine Boulton and Park (on their arrest). He found that Boulton had "an extreme dilation of the anus". When asked by $\mathrm{Mr}$ Davies (for the prosecution) if the anus "opened with facility or anything of that kind", Paul replied that "it was readily opened", and that "the muscles were relaxed". Paul "had never seen anything like it before". Likewise, when questioned about Park, Paul described him as having "extreme dilation of the anal orifice". Davies asked about "discolouration or redness or anything of that kind", to which Paul replied that "a mark", described as "a discolouring of the skin", was evident. However, Paul could not trace the source from whence this discolouration had derived. Paul also stated that there was a "greater relaxation of the muscles" in Park than in Boulton. In order to establish credibility (or lack of) for Paul's evidence, Davies also inquired if Paul had "occasion to examine the persons of men in the same way, of men who have been in a natural condition and as to whom there is no suggestion other than one of a natural condition". Paul had, and also agreed that "the condition of these two defendants [was] different" from what he had previously experienced.

Mr Seymour's cross-examination of Paul (for the defence) can be of further use in elucidating the procedures used by the medical profession in gathering knowledge about sodomy. Firstly, he ascertained that Paul had recently read the writing of August Tardieu, and that, as he had been a student of Alfred Taylor, he had read Medical jurisprudence. Thus Paul was considered to be "in the know" in such matters as sodomy. In order to challenge the credibility of Paul's evidence, it was also confirmed that Paul had examined Boulton and Park for two to three minutes each; he did not use a speculum. Other doctors in the trial considered this inadequate practice. Mr Seymour pressed Paul to say whether he found any scars or marks, and also to describe the condition of the sphincter ani muscle. Paul found that it did not contract "naturally", but that it was "loose and relaxed". It was also established that Paul had not "examined a person with a dilated anus before". Furthermore, other, more experienced, doctors did not find the same evidence.

In preparation for the trial, $\mathrm{Mr}$ Archibald had informed the court that six other expert witnesses were asked to examine the defendants. This was six weeks after Paul's initial investigation. One such was Mr John Rowland Gibson, Surgeon to the Gaol at Newgate. In response to the prosecution's questioning, Gibson related that he had examined Boulton first, and had noted that "There was an abrasion on the posterior part of the anal opening extending from the interior backward; there were within the anal opening 4 or 5 small condylomatous spots-a sort of warty spot; there was mark of a previous operation for fistula". He considered that "Friction, or rubbing the part would be most likely I think to produce it, it was quite superficial". However, Gibson declined to draw any conclusions from the abrasion. Additionally, Park's anus was described by Gibson as follows: "The folds on the left side of the anus did not exist in Park, but they did on the right side". Gibson also noted that 


\section{Ivan Dalley Crozier}

this was an "uncommon condition so far as my experience goes". Gibson had read the two leading Continental authorities on sodomy, August Tardieu and Johann Casper, a fact used by the court to establish a doctor's expertise in detecting sodomical practices.

The counsel for the prosecution, Mr James, asked what Mr Gibson thought the "probable symptoms that would be found after the commission of the crime"; to which Gibson replied: "The symptoms would depend I think a great deal upon the frequency of the commission of the crime; the abrasion of the folds would not arise except from repeated acts". He further noted that "[d]ilation of the sphincter, and the destruction or removal of the folds around the anus" would be the result. Lord Chief Justice Cockburn brought to the court's attention that "although this gentleman has not seen an instance of the effect produced by such a crime, yet if his general anatomical and surgical knowledge enables him to form an opinion, and he is able to say that the result of certain acts must be to produce such an effect, that would be legitimate evidence". Mr Seymour's cross-examination of Gibson ascertained that Gibson had never seen a chancre of the anus. This establishment of ignorance amongst medical practitioners concerning knowledge about sodomy was to become crucial for the conclusion that sodomy did not exist in England, for unlike their Continental colleagues, credible and respectable English doctors at this trial (not Paul) were on the whole unable to tell if it had occurred or not. If it was common, on the other hand, it was assumed that English doctors would have had no trouble in recognizing the fundamental signs and making an accurate diagnosis. In this manner, it was also assumed that sodomy must be a common practice in France and Germany, as Casper and Tardieu had much experience in examining it.

Concerning Boulton, Taylor noted that " $[t]$ here was a slight excoriation-there was a raw part of the skin near the anal aperture". He also reported "a few small warty growths", of which he had no prior experience. Concerning Park, Taylor suggested that "there was only one point with regard to Park's case and that was that what we call the rugæ or at the end of the skin round the orifice were not so distinct as they usually are on one side". Taylor also admitted that he had had only "one case to examine in 38 years of this kind". This had occurred in 1833, and was the body of a deceased man. In response to Mr Seymour's cross-examination, Taylor suggested that "[t]here was nothing there but what might be regarded as natural, even the slight absence of these ridges or furrows of the skin I should not take as indicating anything like unnatural intercourses: I do not think these puckerings are the same in all people". Continuing on this point, Taylor suggested that:

I should not regard it as evidence of the abrasion having been produced by any foreign body for this reason - if you will allow me to add-that there was no dilation or distension of the muscles round the anus, the sphincter ani as we call it, that would have been stretched.

Mr Richard Barwell, Surgeon to Charing Cross Hospital, had treated Park as an outpatient of the Hospital for a chancre on his anus in mid-March, 1870. About Park, Barwell indicated that "[o]n the back part of the anus there was a small mark, it consisted of a small superficial vein of the sort we call hemmoro [sic]". He did not venture to say what caused this vein, although he asserted that, as with Boulton, 


\section{The Medical Construction of Homosexuality}

"the appearances of the parts were suspicious". About Boulton, Barwell claimed that "[t]he first thing that was observable in the examination was that at the back of the part of the anus there was a large superficial excoriation". He also drew attention to "the sore of an old fistula on the left side rather than in the front". Furthermore, Barwell noted that "The anus lay deeper in the parts than usualdepressed ... I mean the parts round the anus receded more into the commencement of the aperture".

Mr Henry William Hughes was once called out to Boulton in 1868 to treat abscess near Boulton's anus. Mr Seymour inquired, "What opinion did you form as to the cause of it [the abscess] - was it caused in your opinion by violence or did it arise from something constitutional?" Hughes responded, "I presumed that it was caused in the usual way in which abscesses are generally formed in that part-probably from an ulceration of the mucous membrane and oozing of the contents of the bowels to the cellular tissues". Hughes had operated on Boulton for fistula. Hughes also noted that, apart from the scar of the previous operation, nothing unusual was found in the appearance of Boulton's anus. Mr Seymour asked if "there anything to afford in your opinion any ground for the suspicion that a foreign substance had ever been introduced there", which Hughes denied. Concerning Park, Mr SergeantParry for the prosecution asked if Hughes had found "any trace whatever upon his person that would indicate an unnatural crime having been committed?" Hughes had not. Furthermore, Hughes did not agree that the rugæ had been obliterated on one side of the anus, as Gibson and Taylor had suggested. Hughes had never made an observation in his life where unnatural practices had been committed. Hughes also did not observe any dilation. Nor had he read Tardieu. In all, Hughes suggested that he had not the necessary experience to examine sodomy cases. Such protestations did much to suggest that sodomy was a rare thing in Britain, again tacitly juxtaposed with the immense amount of Continental knowledge on the subject, supposedly due to the wider existence of such practices across the channel.

Mr Frederic le Gros Clark, examiner at London University and at the Royal College of Surgeons and lecturer at St Thomas's Hospital, spent a quarter of an hour examining both Boulton and Park separately. He noted that he "could not detect in either of those youing men anything even to justify a suspicion that they had been guilty of anything like an unnatural offence". Further, Clark challenged Paul on the dilation of the anus. He thought that the appearance of the roughness of the rugæ varies "very much indeed"; although he noted that he had never examined a case like this before. Nor had Clark read about it: "I have abstained from studying the subject which is repulsive in itself and not likely to be of any service to me professionally". When asked what kind of evidence he might expect to find in cases of sodomy, Clark commented, "I am not prepared to answer that question, for I know nothing of the subject practically"; although he surmised "speaking physiologically, and from the knowledge of anatomy of the parts that it would require a very long period and a repetition of the offence for it to leave any traces of it whatever". Clark had read neither Tardieu nor Casper.

Mr Henry Johnston James, Surgeon at St George's Hospital, found Boulton's anus to be quite contracted, as with Park's. Further, he thought Park's rugæ to be 


\section{Ivan Dalley Crozier}

"quite as marked as usual". Also, James found no traces of venereal disease on Park. James had seen a case before:

At the Lock hospital I saw one case which I did not doubt must have been a case of that description [sodomy]. At the time we were perfectly convinced of it. It was not brought before us criminally and we had nothing to say but to the mere surgical part of it. In that case there was just what one might expect, a large anus and a large rectum. The mucous membrane of the rectum thickened; the external rugæ not nearly so marked as usual and the internal rugæ, in consequence of the dilation of the inner sphincter of the rectum nearly effaced. They are in fact physiological results which must ensue from repeated acts of that kind, which it requires nothing but knowledge of physiology to detect.

In his summing up, the Attorney General, Mr Archibald, made the interesting note that "Happily that is the case with all the medical gentlemen, therefore that vice has not yet tainted the habits of the men of this country-for that thank Heaven". The ignorance of the doctors who tendered evidence at the trial essentially acted as a vindication of the morality of the English nation. The jury passed the verdict not guilty.

The most interesting aspect of the case of Boulton and Park is that all of the medical evidence tendered was purely physical in nature; from this physical evidence, the general conclusion was that the physician could not tell with any degree of accuracy if sodomy had been committed. Knowledge about sodomy in medical circles was scant indeed. This is hardly surprising in late-Victorian times. Even in Germany, where the most important developments in sex psychology were beginning to take place, Carl Westphal had written his article, 'Die conträre Sexualempfindung', only two years prior to the trial. ${ }^{30}$ Sex psychology had not developed to the point where it could advance the concept of "homosexuality", although it was soon to do so on the Continent. ${ }^{31}$ But in England things remained much the same for the time being.

After Boulton and Park's trial, Thomas Stevenson's posthumous editions of Alfred Taylor's writing on sodomy became more detailed, although many of Taylor's original observations remained unrevised. For instance, Stevenson added that "Unless an examination is made soon after the perpetration of the crime, the signs of it will soon disappear". Further he commented that:

[i]n the case of one long habituated to these unnatural practices, certain changes have been pointed out as medical proofs, among them a funnel-shaped state of the parts between the nates, with the appearance of dilatation, stretching, or even a patulous state of the anus, and

\footnotetext{
${ }^{30}$ Carl Westphal, 'Die conträre Sexualempfindung. Symptom eines neuropathischen (psychopathischen) Zustandes', Archive für Psychiatrie und Nervenkrankenheit, 1869,1 , repr. in Hohmann, op. cit., note 26 above; this text was noticed after the trial in an anonymous report on Archive für Psychiatrie, 1869, in Journal of Mental Science, 1871, 16: 422. Westphal's article has been hailed by Michel Foucault as the beginning of a science of sexuality; see Foucault, The history of sexuality, volume 1: An introduction, trans. Robert Hurley, London, Penguin, 1990, p. 43.
}

\footnotetext{
${ }^{31}$ Tarnowsky, op. cit., note 26 above; KrafftEbing, op. cit., note 26 above; Albert Moll, Perversions of the sexual instinct: a study of sexual inversion based on clinical data and official documents, trans. M Popkin, New York, American Ethnological Society, 1976, were the most important psychologists who addressed homosexuality and the law. See Vern Bullough, 'The physician and research into human sexual behaviour in nineteenth-century Germany', Bull. Hist. Med., 1992, 66: 247-67.
} 


\section{The Medical Construction of Homosexuality}

a destruction of the folded or puckered state of the skin in this part. There may be also marks of laceration, cicatrices, \&c., and sometimes the evidence derivable from the presence of syphilitic disease. ${ }^{32}$

Stevenson recognized that the condition of the anus would "represent the chronic state induced by these practices" in the passive partner. He also considered "fissure and laceration of the sphincter ani, with bruising and effusion of blood" 33 would be found in recently committed cases.

By the sixth edition, some thoughts had been developed by Fred Smith, who "revised, edited and brought up to date" Taylor's work. Under the heading 'Unnatural Offences', Smith claimed that "Decency suggests that these should be left unnoticed, but the claims of legal medicine necessitate a brief reference to them". The actual offences which Smith considered were 'Masturbation', 'Indecent Exposure', 'Sodomy', 'Tribadism', and 'Bestiality'. Smith noted that "the law is silent" about masturbation "unless done publicly, and so it is on tribadism" ${ }^{34} \mathrm{He}$ noted that the others were criminal offences. ${ }^{35}$

In establishing the medical evidence necessary to prove the offence, Smith pointed out that "It is asserted that those who are in the habit of practising sodomy (sodomites) exhibit certain general characteristics; but as some undoubtedly do not show such stigmata, it is unnecessary to enumerate them" ${ }^{36}$ However, Smith also assented that it was "not to be expected that any evidence at all would be found on the penis of the active agent unless it were examined immediately after the perpetration". Here the "only possible evidence obtainable would be the peculiar smell of the anal glands transferred possibly to the penis, and possible also traces of fæces on the organ". ${ }^{37}$ As to the signs of passive pederasty: "where they are absent the innocence of the accused should not be presumed in all cases". ${ }^{38}$

\footnotetext{
${ }^{32}$ Taylor, op. cit., note 27, above, vol. 2, p. 459. This kind of evidence was still being used in the 1930s. See John Glaister and John Glaister, $\mathrm{Jr}$, A text-book of medical jurisprudence and toxicology, Edinburgh, Livingstone, 1931, where they write: "The lesions which ought to be looked for by the examiner are of the following character: (a) Recent lacerations of the mucous membrane of the anus; (b) Dilation of anus and absence of puckering of anal introitus, in habitual cases; (c) An infundibuliform-shape of the anal introitus; (d) The presence of old lacerations, as indicated by cicatrices", p. 550.

${ }^{33}$ Taylor, op. cit., note 27 , above, p. 459.

${ }^{34}$ Taylor, Principles and Practice of medical jurisprudence, 6th edition, ed. F Smith, London, John Churchill, 1910, vol. 2, p. 291. Smith further noted: "Masturbation: readers of KrafftEbing's 'Psychopathia Sexualis' will not need to be informed how the practice of this 'crime against self' may easily lead to crime against
}

others. So long as the act is not done openly the law cannot take notice of it, though medical men are aware of its terrible effects", p. 291.

${ }^{35}$ It must be remembered that Smith's revision of Taylor was written after the Criminal Law Amendment Act of 1885 . Smith drew attention to the relevant section: "Any male person who, in public or in private, commits, or is a part to the commission of, or procures or attempts to procure the commission of any male person of, any act of gross indecency with another male person, shall be guilty of a misdemeanour, and being convicted thereof shall be liable at the discretion of the court to imprisonment for a term not exceeding two years", 48 \& 49 Vict. c. 69 , s. 11, in ibid. For more information on this amendment, see Smith, op. cit., note 22 above.

${ }^{36}$ Taylor, op. cit., note 34 above, p. 293.

${ }^{37}$ Ibid.

${ }^{38}$ Ibid., pp. 295-6. Cf. Acton, who suggested the opposite, and was inclined to leniency. 


\section{Ivan Dalley Crozier}

\section{Other Ways of Medicalizing Sodomy: Venereology}

Another writer on aspects of sexuality in England was the much maligned venereologist, William Acton. Acton's writings have been characterized by some as "the official views of sexuality held by Victorian society". ${ }^{39}$ Others have commented that "[h]e wrote for men, about men's problems, and was interested in women primarily as a healthy place ... to deposit their sperm". ${ }^{40}$ However, certain scholars stress that Acton cannot be seen as the archetypical nineteenth-century authority on sexuality. Jeanne Peterson notes that a "careful scrutiny of Acton's medical work uncovers patterns of writing and thinking that reveal his deviant character as a writer and professional man" ${ }^{41}$ Such a view of Acton is perhaps becoming common, as Mary Spongberg recently wrote "far from being a novel approach to prostitution and venereal disease, Acton's work is rather a museum devoted to all the mythologies of prostitution fostered during the nineteenth century", ${ }^{42}$ noting that "Acton's research can only be described as slipshod and haphazard". ${ }^{43}$ Lesley Hall, however, considers Acton in his intellectual context, commenting that he "is more properly regarded as a revolutionary innovator initiating serious medical debate on sex".44

While it is important not to put too much stress on Acton as a resource who can be picked up and utilized in order to get a medical comment upon a sexual issue, ${ }^{45}$ it must be remembered that he was an important player in mid-Victorian sexual medicine. For the purposes of this paper, it is essential to note that Acton was against sodomy as a means to achieving sexual gratification. He was specifically interested in the medico-legal aspects of the crime, and attended to cases "in which no doubt can arrive that contagion has had its source in unnatural intercourse, as the parties were taken in flagrante delicto, or the patients have acknowledged that such had been the origin of the complaint". From these cases, Acton argued, one could derive a "true interpretation of the symptoms" which "is very necessary to medico-legal inquiries". ${ }^{46} \mathrm{He}$ recognized that venereal infections of the anus were due to "direct contact of the blennorrhagic secretion; it cannot be produced by swallowing, as some authors have pretended". ${ }^{47}$

Acton suggested that diagnoses of non-specific venereal infections of the rectum are difficult, especially considering the jurisprudential ramifications of such a diagnosis. He noted that "previous writers have stated that there are certain appearances

\footnotetext{
${ }^{39}$ Steve Marcus, The other Victorians, New York, Basic Books, 1966, p. xix; Havelock Ellis also used Acton as the archetype of Victorian medical discourses on sexuality in 'The erotic rights of women', London, British Society for the Study of Sex Psychology Publication, 1918.

${ }^{40}$ Thomas Laqueur, Making sex: body and gender from the Greeks to Freud, Cambridge, MA, Harvard University Press, 1990, p. 196.

${ }^{41}$ M J Peterson, "Dr" Acton's enemy: medicine, sex and society in Victorian England', Victorian Studies, 1986, 29: 569-90, p. 585.

${ }^{42}$ Mary Spongberg, Feminizing venereal disease, New York University Press, 1997, p. 46.

${ }^{43}$ Ibid., p. 50.
}

\footnotetext{
${ }^{44}$ Hall, op. cit., note 10 above, p. 351 . See also Roy Porter and Lesley Hall, Facts of life, New Haven, Yale University Press, 1995. To situate Acton in his medical and professional context further, see Ivan Crozier, 'William Acton and the history of sexuality: the professional and medical contexts', J. Victorian Culture, 2000, 5: 1-27.

${ }^{45}$ As, say, Lynda Nead does in Myths of sexuality, Oxford, Blackwell, 1988.

${ }^{46}$ William Acton, A practical treatise on diseases of the urinary and generative organs (in both sexes), 2nd ed., London, John Churchill, 1851, p. 330.

${ }^{47}$ Ibid., p. 331.
} 


\section{The Medical Construction of Homosexuality}

of the rectum which betoken the fact that unnatural crimes have been committed". As it was possible for medical men to be cross-examined on these matters, Acton thought it necessary "to allude to the subject, particularly as the liberty and reputation of several individuals depend upon a correct appreciation of the signs in question". While noting that the French surgeon Auguste Cullerier advocated the opinion concerning "the funnel-shaped appearance of the rectum", Acton pointed out that in a case which he had examined, "it was satisfactorily proven that this funnelshaped appearance of the anus does not necessarily follow the commission of an unnatural crime; no such appearance was there present". Additionally, he described how dissection of a phthisical patient demonstrated that "this infundibuliform appearance will often be found, as it depends on the absorption of fat; an inflammatory affection may cause a swelling of the parts around the anus, and give the opening a funnel-shaped appearance". Acton therefore inferred that sodomy could take place "without this sign being present"; he also noted that "if it does exist there is no reason to suppose that the crime has been perpetrated". ${ }^{48}$

Acton elaborated on some of the methods of ascertaining if sodomy had taken place. He commented that in "simple blennorrhagia of the rectum, inoculation affords no assistance". However, if syphilitic chancres were present, "and inoculation produces the characteristic pustule", the case could assume a different aspect especially if the chancre does not exist on any other part of the sexual organs. ${ }^{49}$ There were exceptions to this rule: "if chancres exist on the external organs of the female, there is nothing to prevent the belief that the virus may have dribbled back and provided the affection of the rectum. This is very unusual, but a prisoner should have the benefit of the doubt". 50

Acton recommended caution when considering the "habits of the patient, or the history of the complaint", as these "seldom aid the diagnosis, as in judicial inquiries an acknowledgment of the cause of the disease is not likely to be made". Thus he suggested that medical evidence given in cases of alleged unnatural offences was a difficult subject, for "when no chancre exists, there is no one unequivocal sign that the complaint which the surgeon is called to pronounce upon, depends on a disease contracted in unnatural connexion". However, Acton did note that there is a particular sign upon which his teacher, the Parisian venereologist, Philippe Ricord, laid great stress: "a rent or tearing of the margin opposite the coccyx and perinaeum,

${ }^{48}$ Ibid., pp. 331-2. This material is also dealt with by August Tardieu, Etude médico-légale sur les attentants aux mours, Paris, Librairie J-B Ballière et Fils, 1857, and Casper, op. cit., note 26 above, and is given considerable importance in the trial of Boulton and Park, discussed below.

${ }^{49}$ Inoculation was the practice of extracting some of the pus from a suspect ulcer, and infecting a clean site on the patient's body. If a characteristic syphilitic ulcer appeared in the newly contaminated site, then one could conclude that the original sore was syphilitic. If it did not appear, then the original sore was concluded to be non-specific, caused by gonorrhœa or another such non-specific disease. This theory was developed by Philippe Ricord, pre-germ theory. See Acton, 'On the advantages to be derived from the study of inoculation, in the investigation and treatment of the disease', Lancet, 1839-40, i: 351-4; idem, 'Advantages of inoculation in the venereal disease', Lancet, 1839-40, i: 533-5.

${ }^{50}$ Idem, op. cit., note 46, above, p. 332. Of course, the law in England specified against unnatural acts, which did not necessarily mean male-male sodomy. Theoretically, prior to 1861 , one could go to the gallows for sodomizing one's wife with her consent. 
which [Ricord] never found in persons unaccustomed to the crime". Acton further asserted, "when this condition has been observed", patients, "on being pressed, have avowed and confessed the manner in which the disease has been contracted". 51

Acton also alluded to the control or prevention of same-sex activity between schoolboys in his much-cited sex-education text, Functions and disorders of the reproductive organs. He warned schoolmasters about "the excessive danger of the Platonic attachments that sometimes become fashionable in a school, especially between boys of very different ages". ${ }^{52}$ Acton was not concerned with "ordinary boyish friendship", but with "the sentimental fancy taken by an older boy to a younger, between whom there can be, in the regular course of school, little companionship, and having about it a most unpleasant and dangerous resemblance to passion". ${ }^{53} \mathrm{He}$ suggested that such behaviour was partially exacerbated by "improving the mind by reading the classics": "[t]he doctrine a boy would extract from many classical works would be, that lust can go on unchecked, unattended with evil results, either physically or morally, to the individual, or to society". ${ }^{54}$

Acton, as we have seen, was involved with the law only in so far as to provide more efficacious methodologies for the detection of sodomy, and more detailed descriptions of the results of anal penetration, for forensic medicine. He did not try to challenge the ideas being promulgated by forensic medicine or by the law. Instead, he maintained the basic beliefs regarding same-sex behaviour while adding descriptions of sodomy to its expanding group of sexual objects which could be medicalized.

\section{The Medicalization of Homosexuality: Sex Psychology}

The medicalization of same-sex activity did not rely on forensic medicine alone after Boulton and Park's trial. Nor was it solely concerned with the venereological description of the consequences of anal penetration. Other fields of discourse, most notably sex psychology, began to emerge in order to explain (amongst other things) same-sex behaviour. ${ }^{55}$ Particularly in England, this development took place as an

\footnotetext{
${ }^{51}$ Ibid., p. 332. Acton also noticed that when discussing buboes-swollen lymph nodes-syphilis of the anus could be the cause. When a chancre of the anus existed, an enlargement of the inguinal glands may be noticed, pp. 470-1.

${ }^{52}$ Acton, Functions and disorders of the reproductive organs, 4th ed., London, John Churchill, 1865, pp. 16-17.

${ }^{53}$ Ibid., p. 17.

${ }^{54}$ Ibid., p. 19. Vern Bullough has warned of the danger of mistaking masturbation for homosexuality in mid-nineteenth-century medical texts, so I am basing my conviction that Acton was writing of same-sex behaviour in his references to Juvenal, Martial, Ovid and Byron, and his discussion of "Platonic attachments" derived from Plato's Phadrus (p. 17). See Vern Bullough and Martha Voight, 'Homosexuality
}

and its confusion with the "Secret Sin" in preFreudian America', J. Hist. Med., 1973, 28: $143-55$.

${ }^{55}$ Furthermore, criminologists such as Charles Mercier, at the beginning of the twentieth century, considered the "injury done to society" by unnatural offences "very remote", and thought that the "reprobation and abhorrence with which they [homosexual acts] are regarded" was due to the "degradation of human nature" and "the violation of the racial principle" that they involve. He also noted that homosexuality was treated as criminal, and as such was "punished as a rule with extreme severity", Crime and criminals, University of London Press, 1918, pp. 198-9. See also Mercier, Crime and insanity, London, Home University of Modern Knowledge, 1913, pp. 219-20. 


\section{The Medical Construction of Homosexuality}

active attempt to alter the law. Sex psychology has been associated with cultural developments, such as the "proto-gay liberation" movement which rose throughout Europe, and which sought to have homosexual behaviour decriminalized when committed in private. ${ }^{56}$ In its early stages sex psychology was content to describe clinical cases. This hailed the rise of another style of medical reasoning about the individual: the case study. ${ }^{57}$ In the mid-1880s, George Savage contributed a homosexual case study to the Journal of Mental Science. Savage described a 28-year-old single man who "felt so ashamed of his unnatural state that he wished he were dead, to prevent scandal to his family". ${ }^{58}$ The man, who was very religious, was also hardworking and led a solitary life. He had no desire for women, and doubted that he ever did have. "The sight of a fine man causes him to have an erection, and if he is forced to be in his society he has an emission." 59 Savage commented that this man's "senses appeared to be normal in every respect, and his reasoning powers in no way affected" ${ }^{60}$ He recommended that the man seek mixed society, and that he continue to pursue the musical talent he had formerly given up (as it took him into the company of other men). ${ }^{61}$ Savage questioned whether this "perversion is as rare as it appears", ${ }^{62}$ for he found that it was met with in a number of legal situations, thus again emphasizing the role of the law in making medical practitioners justify their discourses on homosexuality in terms of the law, while also highlighting that the law was not totally effective for eradicating the problem, as the case he was examining was not a legal one. Savage was implicitly suggesting that medical practitioners had more to offer in certain circumstances.

The man of letters, John Addington Symonds, attempted to redress the legal situation in a number of anonymously authored, privately printed, early psychology of sex texts. Like Savage, he drew attention to the fact that even though the law punished homosexual activity, it still persisted, and therefore "ought to arrest attention". He argued that everyone in society was responsible to some extent "for the maintenance and enforcement of our laws" ${ }^{63}$ One of the reasons Symonds demanded treatment of homosexuality in medical and legal literature was that he considered it to be hereditary: "[e]very family runs the risk of producing a boy or girl whose life will be embittered by inverted sexuality, but who in all other respects will be no worse or better than the normal members of the home". He considered it society's duty and interest "to learn what we can about its nature, and to arrive through comprehension at some rational method of dealing with it" ${ }^{64}$ In $A$ problem in modern ethics, Symonds argued that England should adopt the same stance on homosexuality as other European states

\footnotetext{
${ }^{56}$ See the pioneering works by John Lauritsen and David Thorstad, The homosexual rights movement, New York, Times Change Press, 1974; and James D Steakley, The homosexual emancipation movement in Germany, New York, Arno Press, 1975.

${ }^{57}$ See John Forrester, 'If $p$, then what? Thinking in cases', Hist. Human Sci., 1996, 9: 1-25; Ivan Crozier, 'Havelock Ellis, eonism and the patients' discourses; or, writing a book about sex', Hist. Psychiatry, forthcoming.
}

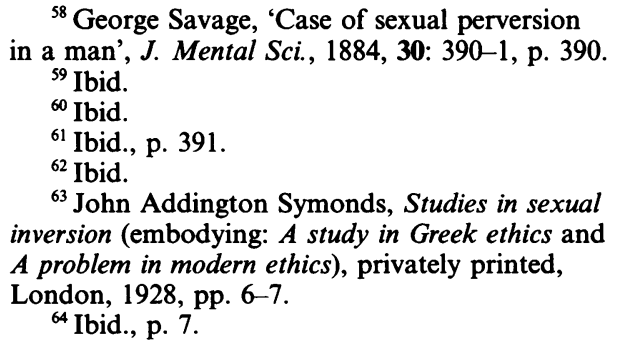
in a man', J. Mental Sci., 1884, 30: 390-1, p. 390.

${ }^{59}$ Ibid.

${ }^{61}$ Ibid., p. 391.

${ }^{62}$ Ibid. inversion (embodying: $A$ study in Greek ethics and $A$ problem in modern ethics), privately printed, ${ }^{64}$ Ibid., p. 7 


\section{Ivan Dalley Crozier}

which had the Napoleonic Code. Under this Code, male homosexual behaviour was illegal only if performed in public, or if it abused minors. ${ }^{65}$

Contrary to many of the Continental approaches to homosexuality, Symonds presented his own categories of homosexual activity: “(1) Forced abstinence from intercourse with females, or faute de mieux; (2) Wantonness and curious seeking after novel pleasure; (3) Pronounced morbidity; (4) Inborn instinctive preference for the male and indifference to the female sex; (5) Epochs of history when the habit has become established and endemic in whole nations" ${ }^{66}$ Symonds elaborated particular aspects of this scheme. For instance, those with an instinctive inborn desire for their own sex "behave precisely like persons of normal sexual proclivities, display no signs of insanity, and have no morbid constitutional diathesis to account for their peculiarity". ${ }^{67}$ This was in distinction to social feeling, which "moulded by religion, by legislation, by civility, and by the persistent antipathies of the majority, regards sexual inversion with immitigable abhorrence". ${ }^{68}$ Thus, for the first time in English writing, homosexuality was being conceived of as a "type", and not as a series of either physical signs or behavioural symptoms. Furthermore, Symonds made a number of suggestions regarding the subject of sexual inversion in relation to the law. He noted that scientific investigation had proved that:

... a very large proportion of persons in whom abnormal sexual inclinations are manifested, possess them from their earliest childhood, that they cannot divert them into normal channels, and that they are powerless to get rid of them. In these cases then, legislation is interfering with the liberty of individuals, under a certain misconception regarding the nature of their offence. ${ }^{69}$

Symonds considered scientific observation had proved that "temperate indulgence of abnormal sexuality is no more injurious to the individual than a similar indulgence of normal sexuality". ${ }^{70}$ Concurrently, Symonds noted that "our laws encourage blackmailing upon false accusation; and the presumed evasion of their execution places from time to time a vile weapon in the hands of unscrupulous politicians, to attack the Government in office". ${ }^{71}$ From these bases, Symonds questioned whether English law was "justified in restricting the freedom of adult persons, and rendering certain abnormal forms of sexuality criminal, by any real dangers to society", especially after it had been shown "that abnormal inclinations are congenital, natural and ineradicable in a large percentage of individuals". Other types of sterile intercourse between the two sexes, he noted, were tolerated; "legislation has not suppressed the immorality question"; the French legal code had not increased this immorality in

\footnotetext{
${ }^{65}$ [John Addington Symonds], A problem in modern ethics: being an inquiry into the phenomenon of sexual inversion, addressed especially to medical psychologists and jurists, privately printed, London, 1891, p. 18.

${ }^{66}$ Ibid., p. 123.

${ }^{67}$ Ibid., p. 124.

${ }^{68}$ Ibid., p. 125.
}

\author{
${ }^{69}$ Ibid., p. 129. \\ ${ }^{70}$ Ibid., p. 129 . There are some similarities \\ between Symonds' reasoning here and Sir James \\ Paget's conception of masturbation. See Paget, \\ 'Sexual hypochondriasis', in Paget, Clinical \\ lectures and essays, 2nd ed., London, Longmans \\ and Green, 1879, pp. 275-98. \\ ${ }^{71}$ [Symonds], op. cit., note 65 above, p. 131 .
}




\section{The Medical Construction of Homosexuality}

France; "the English penalties are very rarely inflicted to the full extent"; and "our higher education is in open contradiction to the spirit of our laws". ${ }^{72}$

Symonds died before any of the legal reforms for which he had argued materialized, as did the prominent English psychologist of sex, Havelock Ellis, with whom Symonds collaborated on the first English medical textbook published on homosexuality, Sexual inversion. Like Symonds' earlier works, Sexual inversion was written for the purpose of redefining homosexuality in the eyes of the law. Ellis and Symonds mooted that "[i]t can scarcely be said that the attitude of society is favourable to the invert's attainment of a fairly sane and well-balanced attitude". This, they thought, was "indeed, one of the great difficulties in his way and causes him [the homosexual] to waver between extremes of melancholia and egoistic exaltation". ${ }^{73}$

Ellis and Symonds' Sexual inversion followed the style of Continental sex psychologists, Richard von Krafft-Ebing and especially Albert Moll. ${ }^{74}$ They intended to describe homosexuality in both men and women, and to demonstrate that homosexuality was but another manifestation of the sexual instinct: itself a natural process. The major difference between homosexuality and "normal" sexuality was that the homosexual had the same sex as the object of their sexual desire. This might seem selfevident to a late twentieth-century reader, but it was a radical proposal in 1897, and one which was supported with many case studies that, like Savage's case above, illustrated how homosexual desire was manifest in an individual. Unlike Krafft-Ebing,

\footnotetext{
${ }^{72}$ Ibid., p. 132. Symonds was referring to the fact that Oxford and Cambridge both denied access to women whilst he was a student. The reader should recall Acton's comments about a classical education, above.

${ }^{73}$ Ellis and Symonds, op. cit., note 26 above, p. 147. Following this, a long footnote in the Williams and Macmillan edition of 1897 , but cut from the London University Press second edition (which I have been using for the rest of the quotations), was used to demonstrate much of what Ellis was arguing. "This is, indeed, one of the great difficulties in his way and causes him to waver between extremes of melancholia and egoistic exaltation. $\mathrm{fn}$ : This is well brought out in a vigorous document by a very able writer, which I may here publish: 'In this case the strength of sin is the law. No passion, however natural, which is scouted, despised, tabooed, banned, punished, relegated to holes and corners, execrated as abominable and unmentionable, can be expected to show its good side to the world. The sense of sin and crime and danger, the humiliation and repression and distress to which the unfortunate Pariahs of abnormal sexuality are daily and hourly exposed-and nobody but such a Pariah can comprehend what these are-inevitably deteriorate the best and noblest element in their emotion. It has been, I may truly say, the greatest sorrow of my life to watch the gradual dwindling and decay of emotions which
}

started so purely and ideally, as well as passionately, for persons of my own sex in boyhood; to watch within myself, I repeat, the slow corrosion and corruption of a sentiment which might have been raised, under happier conditions, to such spiritual heights of love and devotion as chivalry is fabled to have reached-and at the same time to have been continually tormented by desires which no efforts would annihilate, which never slumbered except during weeks of life-threatening illness, and which, instead of improving in quality with age, have tended to become coarser and more contented with trivial satisfaction. Give abnormal love the same chance as normal love, subject it to the wholesome control of public opinion, allow it to enjoy self-respect, draw it from dark places into the light of day, strike off its chains and make it free-and I am confident that it will develop analogous virtues, chequered, of course, by analogous vices, to those with which we are familiar in the mutual love of male and female. The slave has of necessity a slavish soul. The only way to elevate is to emancipate him. There is nothing more degrading to humanity in sexual acts performed between a man and a man than in similar acts performed between a man and a woman. In a certain sense all sex has an element which stirs repulsion in our finer nature"”.

${ }^{74}$ See Krafft-Ebing, op. cit., note 26 above, and Moll, op. cit., note 31 above. 


\section{Ivan Dalley Crozier}

Ellis and Symonds did not employ many different grades of sexual type. Instead homosexuality was, in Ellis and Symonds' eyes, either congenital or acquired.

The role of the case studies was paramount to Ellis's project. In negotiating the text with Symonds, Ellis wrote: "Autobiographies of this kind from England have not been published, and we have no right to assume that they are likely to be similar to the Continental. I don't think we can have too many documents of this kind." Ellis also noted that "a very few carefully detailed are of much greater value than a large number of vague and fragmentary character". The use of fresh autobiographical material was important to Ellis, because, he wrote, "in the whole of the English medico-scientific periodical literature, not a single native case of sex[ual] in[version] has ever been studied, however briefly" ${ }^{75}$

Ellis highlighted the role of case studies in the text. They played a particular part in his claims that if people who were respected, and not criminals and asylum patients, were homosexual, then public opinion should alter, and homosexual activity should not be considered a criminal offence:

I found in time that several persons for whom I felt respect and admiration were the congenital subjects of this abnormality. At the same time I realized that in England, more than in any other country, the law and public opinion combine to place a heavy Penal burden and a severe social stigma on the manifestations of an instinct which to these persons who possess it frequently appear natural and normal. ${ }^{76}$

Ellis and Symonds considered the existing law in England "severe but simple": the ramifications of the 1885 Law Amendment Act made "gross indecency' between males, however privately committed, a penal offence". They also noted that the Criminal Law Amendment Act was "in many respects an admirable enactment: to it we owe the raising of the age at which it becomes lawful for a woman to consent to sexual intercourse from over twelve to over sixteen". But the Act's position on indecency between men was considered "justly subjected to severe criticism", especially the clause discussing grossly indecent acts. Ellis and Symonds' position on the law was that "with the omission of the words 'or private', the clause would be sound and in harmony with the most enlightened European legislation". However, Ellis and Symonds stressed that "an act only becomes indecent when those who perform it or witness it regard it as indecent". Therefore, "[i]f two male persons, who have reached years of discretion, consent together to perform some act of sexual intimacy in private, no indecency has been committed". Moreover, Ellis and Symonds noted that "'gross indecency' between males usually means some form of mutual masturbation". They highlighted that "no penal code regards masturbation as an offence, and there seems to be no sufficient reason why mutual masturbation should be so regarded". ${ }^{77}$ Ellis and Symonds also drew attention to the fact that while the law has had "no more influence in repressing abnormal sexuality than ... it has had at repressing the normal sexual instinct, it has served to foster another offence": blackmail. $^{78}$

\footnotetext{
${ }^{75}$ Ellis to Symonds, 9/2/1893, British Library Add. MS 70524. Of course, this is not quite accurate, see Savage, op. cit., note 58 above.

${ }^{76}$ Ellis and Symonds, op. cit., note 26 above, p. xi.

${ }^{77}$ Ibid., pp. 152-3.

${ }^{78}$ Ibid., p. 155.
} 


\section{The Medical Construction of Homosexuality}

Having considered contemporary legislation, Ellis and Symonds were "of the opinion that neither 'sodomy' ... nor 'gross indecency' ought to be penal offences, except under special circumstances". In other words, "if two persons of either or both sexes, having reached the years of discretion, privately consent to practise some perverted mode of sexual relationship, the law cannot be called on to interfere". Ellis and Symonds considered the function of the law "to prevent violence, to protect the young, and to preserve public order and decency". ${ }^{79}$ They did not think it necessary to persecute homosexuals in order to achieve these aims.

Alas, the approach advocated by sex psychologists like Ellis and Symonds was not heeded by the legal profession. Ellis died in 1939 when $R$. v. Boulton and Park was still referred to in cases of unnatural acts; physical signs were still looked for when other indicting evidence was not forthcoming. ${ }^{80}$ Psychological "justifications" for homosexual desire were not sought. It was only after an important sexological inquiry, tabulated in the Wolfenden Report, that sex acts between men became decriminalized in private. This was in 1967. But attempts to address and, in some cases, change the law provided an important impetus for the development of medical discussions of homosexual acts in England, a point which should not be overlooked.

\section{Conclusion}

Medical writing about homosexuality in nineteenth-century England developed in relation to the law in a number of ways. Firstly, forensic medicine was used in the court in some instances (but far from all, as usually medicine was not relied upon to prove a crime had been committed). Forensic medicine did not challenge the legal definition of sodomy, but rather supplied further evidence necessary to the passage of law. Secondly, venereology added to the corpus of medical knowledge about sodomy by providing detailed descriptions of the physical signs and symptoms of sodomy which were then utilized in medical jurisprudence. Further, venereology did not attempt to alter the legal situation of those who had been charged with committing sodomy, but acted very much in line with forensic medicine in its provision of support for the available medical evidence by which homosexuals could be convicted. Lastly, sex psychology can also be seen to have developed in relation to the law in England in the latter part of the nineteenth century. Unlike those disciplines which relied upon physical evidence, sex psychology rested upon psychological theories of sexual development which were, by and large, imported from the Continent by Havelock Ellis and his colleagues. Ellis's sex psychology, it has been argued, aimed primarily at challenging the legal status of those who indulged in same-sex activity by suggesting that homosexuality was not an unnatural state, and therefore implying that it should not be a criminal offence. Much of the driving force behind the

\footnotetext{
${ }^{79}$ Ibid., p. 156.

${ }^{80}$ This situation was not changed even after the efforts of the feminist, vegetarian, poet and social philosopher, Edward Carpenter, who wrote a number of texts following in the vein of Ellis and especially Symonds. See Carpenter, Love's
}

coming-of-age: a series of papers on the relation of the sexes, London, privately printed, 1930; idem, The intermediate sex, London and Manchester, privately printed, 1908, repr. 1921; idem, The intermediate type among primitive folk, London, G Allen, 1919. 
development of sex psychology came from the liberal political views of its English proponents, particularly of Ellis and Carpenter. ${ }^{81}$ In this sense, the medical challenge to the law, which encapsulated the aims of medical specialization in that it attempted to gain hegemony over a specific area of knowledge, was a part of a political movement as much as it was a medical phenomenon.

It would be a truism to say that medicine and the law were both fields which maintained their power in society by their ability to isolate and define members of that society. In the case of medical theories of same-sex activity we see the challenge to move from the dominance of one discipline (law), which had the support of certain varieties of medicine (venereology and forensic medicine), to a position where a new branch of medicine, sex psychology, became the orthodox medical position on same-sex activity by the mid-twentieth century (although this position was partially superseded by Freudian analysis).$^{82}$ This move can be identified by the invention of new categories (psychological and congenital reasons for homosexual behaviour, rather than the purely deviant behaviour with which the sodomite was accused), which undermined the efficacy of the traditional legal position (that is, once sex psychology's natural model for the homosexual was accepted, it would render legal models of "unnatural" behaviour irrelevant). The fact that sex psychology's attempt to challenge the law as the dominant discourse in the control of same-sex behaviour was primarily unsuccessful does not alter the fact that the law acted as a motor for changes in medical knowledge because of the antagonistic role it played in relation to the growth of medicine in the nineteenth century. This growth was either in support of or in opposition to the law, depending on the field being considered.

Finally, it is possible to theorize the development of the different fields of sexual medicine by referring to some of the ideas of Pierre Bourdieu, and his notion of fields. ${ }^{83}$ Briefly, different fields of practice can be conceived as attempting to gain cultural authority over different objects (in this case, same-sex activity). These fields come into existence via the processes of specialization germane to the wider structure of medicine. As there are going to be a number of different theories posited by different fields, a struggle to posit the orthodox or dominant idea about male-male sexuality is played out over time. What we have seen in the preceding analysis has been a series of challenges to the authority of the law to colonize a particular aspect of society. These challenges have continued to rage throughout the twentieth century as the cultural politics of homosexual behaviour have been addressed by new specialisms such as endocrinology, psychoanalysis and social psychology, as well as by homosexual rights activists throughout the century. In the last analysis, however, it is still very much the law which has the most orthodox position to comment upon same-sex activity, even though the social climate is itself highly heterodox.

\footnotetext{
${ }^{81}$ Sheila Rowbotham and Jeffrey Weeks, Socialism and the new life, London, Pluto Press, 1977, and Christopher Nottingham, The pursuit of serenity: Havelock Ellis and the new politics, Amsterdam University Press, 1999.

${ }^{82}$ See Waters, op. cit., note 13 above.
}

\footnotetext{
${ }^{83}$ Of particular interest here is Pierre Bourdieu, Outline of a theory of practice, trans. $\mathbf{R}$ Nice, Cambridge University Press, 1977, pp. 159-71, and idem, 'The peculiar history of scientific reason', Sociol. Forum, 1991, 6: 3-26.
} 